\title{
INVESTIGATING THE DETERMINANTS OF YOUTH UNEMPLOYMENT IN PAKISTAN
}

\author{
Adnan Ahmad* \& Dr. Farah Khan $\dagger$
}

\begin{abstract}
Youth unemployment is one of the major and burring issues in Pakistan. This study is examining the determinants of youth unemployment in Pakistan for the period of 1991 to 2016. In this study, the model is made of one dependent variable (unemployment) and five independent variables (Population, Foreign Direct Investment, Inflation, Wage Rate and Government Expenditure). The study employed the Ordinary Least Square Method (OLS), Fully Modified Least Squares (FMOLS) and Robust Least Square $(R L S)$. The result shows that foreign direct investment, inflation and government expenditure have significant impact on unemployment in Pakistan during the period under the study. Though, population growth and wage do not show important association with the unemployment rate during the period under this study. In this study Microsoft Excel and E view software is used to analyze the data.
\end{abstract}

Keywords: Unemployment; Inflation; FDI; Government Expenditure; Pakistan.

\section{Introduction}

There are a lot of factor which affect the youth unemployment in Pakistan. The economy of Pakistan mostly depends on agriculture that

\footnotetext{
* M.Sc. Student, Department of Economics, Abdul Wali Khan University, Mardan.

+ Department of Political Science, Women University Mardan.
} 
contributes 20.8 in GDP and $43.6 \%$ people are employed in this sector. Pakistan has great potential of agriculture and at the time of independence agriculture sector played a vital role in economic sector especially in removing the unemployment crises in the country. (Pakistan Bureau of Statistics, 2011). The secondary sector of the economy includes industries that produce finished, usable products or involved in construction. If the government provides loans to the unemployed skilled labor, then it will promote youth. Pakistan industrial sector accounts for about 24\% GDP. Industrial sectored contribute 20.88 percent in GDP. This year it recorded a growth of 5.02 percent as compared to 5.80 percent last year contributes $19 \%$. Another reason for unemployment is our country's poor education policies which are responsible for youth unemployment because there are no institution that provide degree and skills according to the applicable job which is the major problem of all developing country. (International Labour Force Survey, 2010-11). Socially, youth unemployment is not only of concern to the unemployed ones but also to the society and family members. It is the expectation of most youth unemployed to find employment, particularly after completion of their education. Failure to find employment results in demoralization, depreciation in their human capital and deterioration in their employment prediction which leads to social barring (Clark \& Summers 1982). Nowadays, unemployment is the main problem all over the world. The problem of rapidly increasing youth unemployment is due to lack of resources and lack of proper economic planning.

\section{Objective of the Study}

The key objective of this study is to find the relationship of youth unemployment and its effect on Pakistan's economy, and to give some suggestion to the government of Pakistan for the reduction of youth unemployment in Pakistan.

To find causes of youth unemployment in Pakistan and to give good suggestion to the country authority to implement such as policy to reduce youth unemployment ratio in the country.

This article is organized in five parts. Part 1 explain the introduction of the study. Part 2 deals with review of literature. Part 3 discussed data and methodology. Part 4 presents results and discussion. Part 5 deals with conclusion and recommendation of the study. 


\section{Literature Review}

Akhtar, Sajjad \& Shahnaz (2005) studied the factor which affect the youth unemployment in Pakistan. In this study, they are using the time series data from 1991 to 2004. They found that youth unemployment is higher due to low GDP and investment. They operate both macro and micro economic determinants which affect the youth unemployment in Pakistan. They showed that if the annual growing rate of GDP is greater than $4.26 \%$ each year then the youth unemployment ratio begin to decrease. They also showed that the private sector has greater impact on public sector because due to decrease in youth unemployment ratio.

Rocha \& Divin (2013) studied the link between taxes on household expenditure, interest rate and exchange rate in Brazil and Mexico. The data is analyzed by using autoregressive model and distribute lag modes. The results indicated that in both countries, interest rate is positively related whereas taxes on household consumption is negatively related to unemployment, however exchange rate is positively linked with Brazil and negatively linked in Mexico.

Rehman (2012) explained that Pakistan's economy has enclosed a long space from backward to rising period and is now achieving the period of impersonation. Throughout the duration, it has faced a number of confrontation and problems. The major difficulty relates to facilitating ever growing population through providing them jobs. The economy being fundamentally agronomy had excess labor. The process of automation of agriculture has added extra fuel to the fire and subsequently provoked the problem because of extra labor rendered surplus by the farming parts. $\mathrm{He}$ focused on these essential issues and areas and proposed feasible measures for that matter dropping the stage of unemployment. Umair \& Ullah (2013) investigated the effect of inflation on GDP in youth unemployment for the case study of Pakistan. In that paper, they used the time series data from 2000 to 2010. In the study the data was taken from secondary source. The outcome of this study showed that the inflation insignificantly influences to GDP and unemployment in the correlation is negative.

Misgwa \& Kipesha (2013) examined those factors which determine the youth unemployment in Tanzania. In this study, they are using Multinomial Logistic Regression (MLM) model to investigate the determinants of youth unemployment in Tanzania. They concluded that femininity, environmental

location, education, skills and marital position are all significant factors in explaining the difference in youth unemployment. Wajid \& Kalim (2013) examined the determinant of inflation and economic growth besides the 
trade openness and metropolitan inhabitants on youth unemployment for the case study of Pakistan and they used the data from 1973 to 2010. They used the Augmented Dickey Fuller test to find the unit root and to arrange the long run relationship between unemployment, inflation, economic growth trade opens and urban population as part of the total population. They showed that inflation drastically raises unemployment in the long run and also showed that economic growth has significant relationship with unemployment both in the extended as well as in the small term. Correspondingly, it also showed that the impact of trade openness is positive on unemployment and showed that it is insignificant.

Arsalan \& Zaman (2014) used FDI, gross domestic product rate, inflation and population rate as regressors. The result showed that FDI, income (GDP) rate and rate of inflation have inverse effect on unemployment. Population rate has positive influence on unemployment. Azam et al. (2015) examined the relationship between unemployment and military expenditures by using the data for the period of 1990 to 2013 for the South Asian Association Region SAARC countries (India, Nepal, Pakistan and Sri Lanka). They used multivariate framework for estimation. The study concluded that armed expenditures has good turn the employment rate in the (SAARC) state, as the estimated coefficient of military expenditure has a negative and more flexible relationship with the unemployment rate.

O'Nwachukwu and Increase (2017) studied the determinants of youth unemployment rate in Nigeria. They used the time series data for the period of 1980 to 2016. In this study, they used one dependent variable which is unemployment and five explanatory variables which are Government Expenditure, Inflation Rate, Population and Real Gross Domestic Products. They used (OLS) technique to approximation the model after using the Augmented Dickey-Fuller to test for unit root. They concluded that Government Expenditure, Inflation Rate and Population have statistically significant changes in unemployment in Nigeria. The study recommended that corrupt officials who misappropriate money must be punished accordingly.

Kamran et.al., (2016) examined the determinant of unemployment in Pakistan. They are using the time series data for the period of 1881to 2010. Results demonstrate that it is usually perceived that unemployment in rural area is more due to fewer chances of employment as compared to urban areas where there are more probabilities of employment due to a lot of industries. There are different theories about the unemployment such as classical and new classical. But the classical theories about the unemployment say that the economy will achieve full employment when wages and prices are flexible. The classical view states that the 
unemployment situation occurs when wages rise too high to maintain the equilibrium. When wage rise, then firms cannot pay many workers, so they fire or lay off them, rising unemployment.

On the other side, the new classical economists such Keynesian economics says that the macro economy can be in imbalance for a substantial time. Keynesian economics says that there should be government interference to help to defeat the lack of aggregate demand to reduce the unemployment and increase the growth rate (Pettinger, 2017). Khraief et al. (2018) studied the unemployment rate in case of 29 OECD countries during of 1980-2013. The results indicate that unemployment hysteresis hypothesis is strongly rejected.

\section{Data and Methodology}

The following chapter consists of empirical model and methodology, data and data source.

\section{Data Source}

Time series data is used for the period of 1991 to 2016 to find the determinants of youth unemployment in Pakistan. All the data is collected from World Development Indicator (WDI) which is published by World Bank.

In this study, five variables are used namely Unemployment, Population, FDI, Inflation, Interest rate, Government spending.

\section{Econometric Model}

In this study we use the following model

Unemployment Rate $=\beta_{0}+\beta_{1} \mathrm{POPG}+\beta_{2} \mathrm{FDI}+\beta_{3} \mathrm{INF}+\beta_{4} \mathrm{WAGE}+\beta_{5} \mathrm{GEX}+\varepsilon$

Where in equation (1), UR shows unemployment rate (total youth unemployment (\% of total labor force ages 15-24) (modeled ILO estimate), the POPG show the population growth (Population growth (annual \%), FDI show foreign direct investment (Foreign direct investment, net inflows (\% of GDP), INF show inflation rate (Inflation, GDP deflator (annual \%), WAGE show the wage rate (Wage and salaried workers, total (\% of total employment), GEX show government expenditure (General govt consumption spending (\% of GDP), $\varepsilon$ is the error term. 


\section{Result and Discussion}

In this chapter, we include descriptive statistic, tables and interpretation of the tables. In this section, we conduct the Augmented Dickey Fuller test to find the stationary of the variables through unit root test. We run the model such Ordinary Least Square (OLS) method, Fully Modified Ordinary Least Square (FMOL) method and Robust Least Square (RLS) method and also interpret the Tables of this model.

In this chapter, first of all we will estimate the unit roots to find the stationarity of the variables. So for this we use ADF test.

Unit Root Test: A unit root test is defined as if a time series variable is nonstationary then we possesses a unit root test. It is also called a unit root process or differences stationary process

A key concept underlying time series process is that of stationarity. A stationary time series is one whose statistical properties such as Mean, Variance, Autocorrelation, etc. are all constant over time. A stationary time series has three properties.

$$
\text { (1) } \begin{aligned}
\mathrm{E}(\mathrm{Y}) & =\text { constant for all } \mathrm{t}(2) \operatorname{Var}(\mathrm{Y}) \\
& =\text { constant for all } \mathrm{t}(3) \operatorname{Cov}(\mathrm{Y}, \mathrm{Y}) \\
& =\text { constant for all } \mathrm{t} \& \mathrm{k} \neq 0
\end{aligned}
$$

In Table 4.1 in OLS method, the unemployment is dependent variable. And the others are explanatory variable as POPG, FDI, INF, WAGE, GEX.

So in this table the FDI which is explanatory variable significantly influence the dependent variable which is $\mathrm{UN}$ because the P-value is less then $(0.05 \%)$ which is $(0.0023)$ mean that the relationship between FDI and $\mathrm{UN}$ are significant, further more GEX is also significant to UN because the P-value of UN is also less then (0.05\%) which is (0.0000) meaning that GEX and $\mathrm{UN}$ are significantly correlated with each other.

R-Squared: In the given Table we can also see the value of R-squared which is (0.83) meaning that $83 \%$ are $\mathrm{X}$-variables that have been explained during the study or estimation, the R-squared of this study is to be greater than $60 \%$ meaning that we can accept the model and we are happy about that because if the R-squared is less than $60 \%$ then we reject the model but in this case R-squared is more than $60 \%$ which is a green signal so we accept the model. 
P-value (F-statistic): The F-statistic P-value is also less than $(0.05 \%)$ which is $(0.00000)$ meaning that we cannot reject the model rather we accept the model.

Durbin-Watson stat: In the OLS model the Table shows that the DurbinWatson stat are more than (2) meaning that we accept the model because we know that if the Durbin-Watson value are close or more than (2) than we accept the model and if it is less than two than we reject the model.

Table 4.1:OLS Results

\begin{tabular}{|l|c|c|c|c|}
\hline \multicolumn{1}{|c|}{ Variable } & Coefficient & Std. Error & t-Statistic & Prob. \\
\hline POPG & 3.908553 & 2.010829 & 1.943752 & 0.0661 \\
\hline FDI & -0.881015 & 0.251945 & -3.496859 & 0.0023 \\
\hline INF & -0.109234 & 0.057311 & -1.905970 & 0.0711 \\
\hline WAGE & 0.400870 & 0.218499 & 1.834655 & 0.0815 \\
\hline GEX & -0.906948 & 0.175324 & -5.172973 & 0.0000 \\
\hline C & -1.492277 & 11.61495 & -0.128479 & 0.8991 \\
\hline Adj.R ${ }^{2}$ & 0.793135 & \multicolumn{4}{|l}{ S.D. dependent var } & 2.023842 \\
\hline F-statistic & 20.17038 & \multicolumn{4}{|l}{} \\
\cline { 1 - 3 } $\begin{array}{l}\text { Durbin- } \\
\text { Watson stat }\end{array}$ & 2.544997 & \multicolumn{4}{|l}{}
\end{tabular}

In the Table 4.2 FMOLS method the UN is dependent variable. And the other are explanatory variables which as POPG, FDI, INF, WAGE, GEX.

In this table the FDI which is explanatory variable significantly influence to the dependent variable which is UN because the P-value is less the $(0.05 \%)$ which is $(0.0011)$ meaning that the relationship between FDI and $\mathrm{UN}$ is significant and the other variable INF which is significant to the dependent variable UN because its P-value is also less then $(0.05 \%)$ which is (0.0121) means that the relationship between INF and UN is significant. Furthermore the other explanatory variable is significant which is GEX because its P-value is less then $(0.05 \%)$ which is $(0.0000)$ so the relationship between GEX and UN is significant.

R-Square: In the given Table we can also see the value of R-squared which is $(0.880174)$ meaning that $88 \%$ are $\mathrm{X}$-variables have been explain during the study or estimation, the R-squared of this study is greater than $60 \%$ meaning that we can accept the model and we are happy about that because if the R-squared less than $60 \%$ then we reject the model but in this case Rsquared more than $60 \%$ which is the good result so we accept the model. 
Table 4.2: Fully Modified Least Squares (FMOLS) results

\begin{tabular}{|c|c|c|c|c|}
\hline Variable & Coefficient & Std. Error & t-Statistic & Prob. \\
\hline POPG & 3.544557 & 1.815383 & 1.952512 & 0.0658 \\
\hline FDI & -0.840068 & 0.219165 & -3.833045 & 0.0011 \\
\hline INF & -0.139050 & 0.050101 & -2.775377 & 0.0121 \\
\hline WAGE & 0.369673 & 0.193342 & 1.912019 & 0.0711 \\
\hline GEX & -0.980401 & 0.153676 & -6.379676 & 0.0000 \\
\hline $\mathrm{C}$ & 1.449697 & 10.43411 & 0.138938 & 0.8910 \\
\hline $\begin{array}{l}\text { Adjusted R- } \\
\text { squared }\end{array}$ & 0.848641 & \multicolumn{2}{|c|}{ S.D. dependent var } & 2.064679 \\
\hline $\begin{array}{l}\text { S.E. of } \\
\text { regression }\end{array}$ & 0.803262 & \multicolumn{2}{|c|}{ Sum squared resid } & 12.25937 \\
\hline $\begin{array}{l}\text { Long-run } \\
\text { variance }\end{array}$ & 0.640941 & & & \\
\hline
\end{tabular}

In the Table 4.3 the $\mathrm{UN}$ is dependent variable and the other variables are explanatory variable as POPG, FDI, INF, WAGE, GEX.

In this method the FDI which is explanatory variable is significantly because its P-value is less then $(0.05 \%)$ which is $(0.0000)$ so FDI significantly influence the UN and the other variable INF is also significant because its P-value is less then $(0.05 \%)$ which is $(0.0243)$ so the relationship between INF and UN is significant. Furthermore the other explanatory variable is GEX which is significant because its P-value is less then $(0.05 \%)$ which is $(0.0000)$ which show that the relationship between GEX and UN is significant.

R-Squared: In the given Table we can also see the value of R-squared which is (0.664689) meaning that 66\% X-variables have been explained during this study or estimation, the R-squared of this study is greater than $60 \%$ meaning that we can accept the model and we are happy about it because if the R-squared less than $60 \%$ than we reject the model but in this case R-squared more than $60 \%$ which is the green signal so we accept the model. The results of the present study is matching the previous studies including Khan et al (2015), Maqbool et al. (2013), Wajid \& Kalim (2013) Alshamsi etal. (2015), Azam et al. (2014); Cheema \& Atta (2014), Muhammad et al. (2014), Khan et al. (2014), Azam and Rashid (2015), Yien et al.(2018), Azam \& Khan (2018), Muhammad (2016), Yien et al. (2017ab) and O’Nwachukwu and Increase (2017). 
Table 4.3: Robust Least Square (RLS) results

\begin{tabular}{|l|c|c|c|c|}
\hline \multicolumn{1}{|c|}{ Variable } & Coefficient & Std. Error & z-Statistic & Prob. \\
\hline POPG & 2.837743 & 1.793397 & 1.582329 & 0.1136 \\
\hline FDI & -0.922415 & 0.224702 & -4.105064 & 0.0000 \\
\hline INF & -0.115089 & 0.051114 & -2.251601 & 0.0243 \\
\hline WAGE & 0.352758 & 0.194873 & 1.810197 & 0.0703 \\
\hline GEX & -1.019591 & 0.156366 & -6.520523 & 0.0000 \\
\hline C & 3.816008 & 10.35902 & 0.368375 & 0.7126 \\
\hline Robust Statistics & \multicolumn{5}{|c|}{ Adj. R $^{2}$} \\
\hline $\mathrm{R}^{2}$ & 0.664689 & \multicolumn{5}{|c|}{0.580862} \\
\hline Rw-squared & 0.922692 & Adjust Rw-squared & 0.922692 \\
\hline Akaike info criterion & 44.54089 & Schwarz criterion & 53.74812 \\
\hline Deviance & 11.69429 & \multicolumn{5}{|c|}{ Scale } & 0.584759 \\
\hline Rn-squared statistic & 160.1942 & Prob (Rn-squared stat.) & 0.000000 \\
\hline \multicolumn{4}{|c|}{ Non-robust Statistics } & \\
\hline Mean dependent var & 10.39231 & \multicolumn{5}{|c|}{ S.D. dependent var } & 2.023842 \\
\hline S.E. of regression & 1.013982 & \multicolumn{5}{|c|}{ Sum squared resid } & 20.56318 \\
\hline
\end{tabular}

Table 4.4: Comparison of OLS, FMOLS and RLS

\begin{tabular}{|c|c|c|c|}
\hline Vari & Method (OLS) & Method (FMOLS) & Method (RLS) \\
\hline POPG & $\begin{array}{l}3.908553 \\
{\left[\begin{array}{ll}\text { SE } & 2.010829\end{array}\right]} \\
\text { (t-ratio } 1.943752)\end{array}$ & $\begin{array}{l}3.544557 \\
{[\text { SE } 1.815383]} \\
\text { (t-ratio } 1.952512 \text { ) }\end{array}$ & $\begin{array}{l}2.837743 \\
\text { [SE } 1.793397] \\
\text { (t-ratio } 1.582329)\end{array}$ \\
\hline FDI & 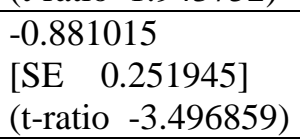 & $\begin{array}{l}-0.840068 \\
\text { [SE } 0.219165] \\
\text { (t-ratio }-3.833045)\end{array}$ & $\begin{array}{l}-0.922415 \\
{[S E 0.224702]} \\
\text { (t-ratio }-4.105064)\end{array}$ \\
\hline INF & $\begin{array}{l}-0.109234 \\
{[\text { SE } 0.057311]} \\
\text { (t-ratio }-1.905970)\end{array}$ & $\begin{array}{l}050 \\
.050101] \\
0-2.775377)\end{array}$ & $\begin{array}{l}-0.115089 \\
{\left[\begin{array}{ll}\text { SE } & 0.051114] \\
\text { (t-ratio } & -2251601)\end{array}\right.}\end{array}$ \\
\hline $\mathrm{Wa}$ & $\begin{array}{l}0.400870 \\
\text { [SE } 0.218499] \\
\text { (t-ratio } 1.834655)\end{array}$ & 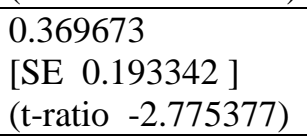 & $\begin{array}{l}0.352758 \\
{[\text { SE } 0.194873]} \\
\text { (t-ratio } 1.810197 \text { ) }\end{array}$ \\
\hline GEX & $\begin{array}{l}-0.906948 \\
{[\text { SE } 0.175324]} \\
\text { (t-ratio } \quad-5.172973)\end{array}$ & $\begin{array}{l}-0.980401 \\
{[\text { SE } 0.153676]} \\
\text { (t-ratio }-6.379676)\end{array}$ & 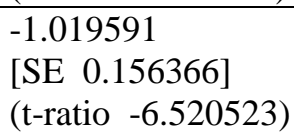 \\
\hline $\mathrm{C}$ & 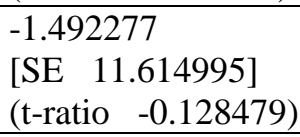 & $\begin{array}{l}1.449697 \\
\text { [SE 10.43411] } \\
\text { (t-ratio } 0.138938)\end{array}$ & $\begin{array}{l}3.816008 \\
\text { [SE } 10.35902] \\
\text { (t-ratio } 0.368375 \text { ) }\end{array}$ \\
\hline
\end{tabular}




\section{Conclusion}

In this study we examined the impact of POPG, FDI, INF WAGE and joblessness in case of Pakistan for the period of 1991 to 2016. First we collected the variable of data then found the stationarity of that variable through unit root test. After that we applied the OLS, FMOLS and RLS method. These three methods gave good and similar results. And then we concluded that foreign direct investment (FDI), inflation (INF) and government expenditure (GEX) have significant effect on unemployment. The paper shows that the (FDI) foreign direct investment, (INF) inflation and (GEX) government expenditure have negative relationship with unemployment. And wage rate (WAG) and population growth (POPG) have positive relationship with out of work.

It is suggested that the regime must focus on to encourage external investors. Supervision must be taken on strategies for enticing foreign investors to encourage and support the investor to come and invest. The government should also focus on foreign investor security. Government should also control corruption, nepotism, bribery and inflation rates for controlling the unemployment. The government should also focus on merit to select the person on merit basis. Now a days the Pakistan China Economic Corridor appears to the be a very crucial project for Pakistan. This project will help to provide a much needed base to kick start economic growth and create a lot of employment opportunities. The government authority should also know which project is beneficial for removing unemployment in the country. make proper policies for skillful people and to encourage these people on every step. The government should also focus on industrial sector and provide financial assistance them.

\section{References}

Akhtar, S., \& Shahnaz, L. (2005). Understanding the Youth Unemployment Conundrum in Pakistan: A Macro-Micro Analysis. Indian Journal of Labour Economics, 49(2), 233-248.

Alshamsi K.H., Hussin R.M., and Azam M. (2015). The impact of inflation and GDP per capita on foreign direct investment: the case of United Arab Emirates. Investment Management and Financial Innovations, 12(3): 132-141.

Azam, M. \& Khan, S. (2018). Inflation and the economic growth: evidence from Five Asian Countries. Pakistan Journal of Applied Economics, 28(2), 235-252. 
Azam, M., and Rashid, S. (2015). The monetarist hypothesis of inflation in Pakistan - a critique. Journal of the Asia Pacific Economy, 20 (4): 559576.

Azam, M., Khan, A.Q., and Stefanescu, L. (2014). Determinants of stock market development in Romania. Journal of Applied Economic Sciences, IX, Issue 4(30), 561-570.

Azam, M., Khan, F., Zaman, K., \& Rasli, A. M. (2015). Military expenditures \& unemployment nexus for selected South Asian countries. Social Indicators Research, 127(3), 1103-1117.

Cheema, A.R., \& Atta, A. (2014). Economic determinants of unemployment in Pakistan: Co-integration analysis. International Journal of Business and Social Science, 5(3), 40-45.

Clark, K.B., \& Summers, L.H. (1982). The dynamics of youth unemployment. In The youth labor market problem: Its nature, causes, \& consequences, University of Chicago Press, 199-234.

Khan, A.Q., Azam, M., Samsi, A., Emirullah, C., \& Usman, M., (2015). Impact of defense spending on unemployment in five countries from Asia. Corporate Board: Role, Duties \& Composition, 11(3),117-129.

Khan, A.K., Azam, M., \& Qureshi, M.I. (2014). Analysis of consumption behaviour concerning current income and lags consumption: Empirical evidence from Pakistan. EkonomskiVjesnik/Econviews: Review of Contemporary Entrepreneurship, Business, and Economic Issues , XX VII (1), 59-70.

Khraief, N., Shahbaz, M., Heshmati, A., \& Azam, M. (2018). Are unemployment rates in OECD countries stationary? Evidence from univariate and panel unit root tests. North American Journal of Economics and Finance, available at https://www.sciencedirect.com/science/article/abs/pii/S1062940818301 050 .

Maqbool, M.S., Mahmood, T., Sattar, A., \& Bhalli, M.N. (2013). Determinants of unemployment: Empirical evidences from Pakistan. Pakistan Economic \& Social Review, 51, 191-208.

Muhammad, A. (2016). Does governance and foreign capital inflows affect Economic Development in OIC countries? Journal of Economic Cooperation and Development, 37(4), 21-50.

Muhammad, A., Khan, S., Ștefanescu, L. (2014). Investigating the stability of Philips curve: panel data evidence from developing world. Challenges to Financial Stability-Perspective, Models and Policies" Volume II- Towards the Financial Stability-Macroprudential Policy and Perspective, (Ed. RenataKarkowska), Chapter 19, ASERS Publishing, 
Craiova, Print ISBN: 978-606-8689-03-6, Online ISBN: 978-606-868904-3. pp- 180-195.

O'Nwachukwu \& Increase, C. (2017). Determinants of the rate of unemployment in Nigeria. International Journal of Information Research and Review, 4(01), 3593-3595.

Pakistan Bureau of Statistics,

Rehman (2012). The Problem of Unemployment in Pakistan: (A case of study of Khyber Pakhtunkhwa) International Journal of Humanities \& Social Science, 2(8), 237-243.

Wajid, A., \& Kalim, R. (2013). The impact of inflation \& economic growth on unemployment. In Proceedings of 3rd International Conference on Business Management.

Yien, L.C., Abdullah, H., \& Azam, M. (2017). Granger Causality Analysis between Inflation, Debt and Exchange Rate: Evidence from Malaysia. International Journal of Academic Research in Accounting, Finance and Management Sciences, 7(1), 189-196.

Yien, L.C., Hussin, A., \& Azam, M. (2018). Monetarism or Keynesian Discourse in Indonesia. Bulletin of Indonesian Economic Studies.

Yien, L.C., Abdullah, H., \& Azam, M. (2017). Monetary Policy Inclusive Growth: Empirical Evidence from Malaysia. International Journal of Academic Research in Accounting, Finance and Management Sciences, 7(1), 225-235. 